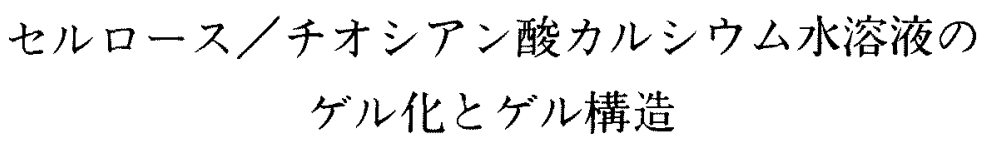

旭化成工業(基碟研究所 服部真貴子・宦谷芳彦 紊藤政利・岡島邦彦

\title{
Gelation and Gel Structure of Cellulose/aqueous Calcium Thiocyanate Solution System
}

\author{
Makiko Hattori, Yoshihiko Shimaya, Masatoshi Saito, and Kunihiko Okajima
}

Central Research Laboratories, Asahi Chemical Industry Co., Ltd. 11-7, Hacchonawate, Takastuki, Osaka 569-0096, Japan

\begin{abstract}
The gelation conditions of cellulose/aqueous calcium thiocyanate solution system were determined by temperature jump method and the structure of the gel was analyzed by DSC and X-ray measurements. The time necessary to occurring gelation was shorter for the higher molecular weight sample, the solution with higher concentration, and at lower temperature. For the all solutions, cloud point was observed before occurring gelation, suggesting that the gelation was induced by liquid-liquid two phase separation. The heat to formation of $1 \mathrm{~mol}$ of network junctions in the gel and the mean molecular weight of the chain adjoining adjacent crosslinks were estimated from melting point determined by ball drop method and the heat of fusion by DSC. The X-ray diffraction curve indicated that the gel is almost amorphous.
\end{abstract}

(Received 15 October, 1998 ; Accepted 26 December, 1998)

\section{1. 緒言}

セルロースを繊維，分離膜，およびフィルムなどに湿 式成型する工程においては，凝固過程での水素結合の再 生，および結晶化によりゲル化が起こる場合が多い。 れら成形体の物性はゲル化の条件によって左右され，ゲ ル化条件と成型体の棈造との関係を把握することは重要 である.しかし，セルロースのゲル化現象，およびその メカニズムに関する報告は必ずしも多くはない.Kamide らは， $4{ }^{\circ} \mathrm{C}$ のルロース/9\%水酸化ナトリウム $(\mathrm{NaOH})$ 水溶液を $-5{ }^{\circ} \mathrm{C}$ 付近へ洽却すると熱可逆ゲルを, 一方, $30^{\circ} \mathrm{C} の$ 高温にすると不可逆ゲルを形成し，同系が $2 つ の ~$ ゲル化領域を持つことを明らかにした[1].また, Hudson らはセルロース/液体アンモニアノチオシアン酸アンモ ニウム溶液を冷却することによって $23^{\circ} \mathrm{C}$ 付近に融点を持
つアモルファス性の熱可逆ゲルが得られることを報告し ている[2].セルロース/チオシアン酸カルシウム水溶液 $\left(\mathrm{aq} \cdot \mathrm{Ca}(\mathrm{SCN})_{2}\right)$ 系についても加熱によってセルロースが 溶解し，その溶液は冷却によって熱可逆なゲルを形成才 る現象が古くから知られていた[3].我々はこれまでにこ の系の溶解挙動・溶解状態などの研究から,濃厚なaq.Ca $(\mathrm{SCN})_{2}$ が, 室温で木材パルプと付加化合物を生成し，さ らに加熱によりそのセルロースを溶解する[4], また水和 した非解離の構造を持った $\mathrm{Ca}(\mathrm{SCN})_{2}$ がセルロースのC5 およびC6位の酸菜原子に溶媒和し，セルロース固体の水 素結合を切断して，七ルロースの誘導体化を伴わずに溶

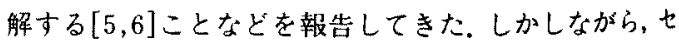
ルロース $/ \mathrm{aq} \cdot \mathrm{Ca}(\mathrm{SCN})_{2}$ 溶液を冷却した時に形成される 熱可逆ゲルに関しては，その形成メカニズムやゲル構造 など不明な点も罗い，そこで，本報告ではセルロース／ 
$55 \mathrm{wt} \%$ aq.Ca(SCN) 2溶液系のゲル化の相图およびそのゲ 几構造を明らかにすることを目的とした。

\section{2. 実験}

\section{1 試料}

セルロースはアラスカパルプ社製のconifer pulp(Sample code : A970)と、これを $25 \mathrm{wt} \% \mathrm{aq} . \mathrm{H}_{2} \mathrm{SO}_{4}$ で加水分解した 分子量の異なる 5 点のサンプル (Sample code：A760, A 550, A430，A290，A180)，およU゙キュプラアンモニウム 溶液からの再生セルロースであるべンリーゼ囚(旭化成工 業橉慗, Sample code：B870)を用いた. 各Sample code の数字は,カドキセン粘度による粘度平均重合度 [7]を示 †.

チオシアン酸カルシウム水溶液は和光純薬慗 (大阪) Ca $(\mathrm{SCN})_{2} \cdot 4 \mathrm{H}_{2} \mathrm{O}$ 亿イン交換水に約 $60 \mathrm{wt} \%$ になる上う溶解 L, これを邊心分離 $\left(45^{\circ} \mathrm{C}, 5 \times 10^{4} \mathrm{G}, 60\right.$ 分, Hitachi model CR20B2)して，わずかに含まれる白色の不溶物を 除いた上澄み液をさらにG4のガラスフィルターで吸引濾 過した，滤液中のチオシアン酸イオンの濃度を硝酸銀水 溶液,チオシアン酸カリウム水溶液を用いた逆滴定 [4]で 求为， $\mathrm{Ca}(\mathrm{SCN})$ 2 濃度が5 $5 \mathrm{wt} \%$ になるように計算量のイ オン交換水䘮加えて $55 \mathrm{wt} \% \mathrm{Ca}(\mathrm{SCN})_{2}$ 水溶液を調製した。

\section{2 セルロース溶液調製}

セルロース試料はあらかじめ60-70 燥させた。乾燥後，科量したセルロースに所定濃度にな るように55wt\%aq.Ca(SCN) 2 を加之室温で1晚浸漬して

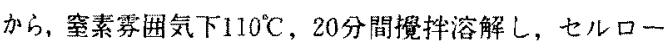
ス溶液を調製した。

\section{3 相図}

セルロース分子量・漂度の異なるセルロース溶液を冷

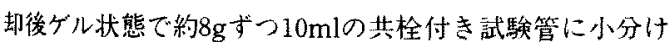
した，試騃管内の架気を窒素がスで置換し，共栓をし， さらにシールテープを撒いて密封した。サンプリングの 際ゲル化していたサンプルを、試駼管ごと110Cのオイル バスに20分間入れ，完全に溶解し熱履歴を除いてから，

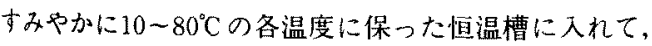
温度ジャンプきせた相状態を目視て観察し, 落球法(SUS 3043/22インチ)および倒置法で溶液の流動性が無くなる 状態をケルと判定した。

\section{4 ケル強度}

約 $300 \mathrm{~g} の$ セルロース/ $55 \mathrm{wt} \% \mathrm{aq} . \mathrm{Ca}(\mathrm{SCN})_{2}$ 溶液を, 溶 解後速やかに $500 \mathrm{ml}$ のビーカーに移し、ビーカーを直ちに $25^{\circ} \mathrm{C}$ 保った恒温槽中に入れゲル化を開始した。内径 $2 \mathrm{~cm}$ のコルクボーラーで経時的にゲルをサンプリングし,2cmф × $1 \mathrm{~cm}$ の内筒形のゲルを切り出した。切り出したゲルの 圧縮応力をレオメーターCR-200D (俶サン科学)を用い,

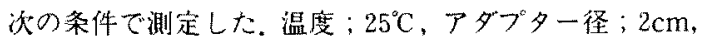
压縮速度； $60 \mathrm{~mm} / \mathrm{min}$, 压縮距離； $1 \mathrm{~mm}$.

\section{5 ゲルの融点}

セルロース分子量・濃度の異なるセルロース溶液を， 冷却後ゲル状態で約 $5 \mathrm{~g}$ オ゙つ $10 \mathrm{ml}$ の权じ口瓶にサンプリン グした、これを容器ことと1100のオイルバスに20分間入れ， 完全に溶解し一相にしてから，すみやかに $-20^{\circ} \mathrm{C}, 0^{\circ} \mathrm{C}$, $25^{\circ} \mathrm{C}, 40^{\circ} \mathrm{C}$ 各温度に保った恒盜槽に入れて, 温度ジャ ンプきせ, 1 週間その温度で保ちゲルを形成させた。ゲ ル化させたサンプルをオイルバスに入れ，室温から1分 間で $1{ }^{\circ} \mathrm{C}$ 舁温し，9分間その温度に保つことを繰り返し ながら，ゲルが融解するまで昇温した。ゲルの融解は落 球法で判定した。ただし，低分子量，低濃度の領域はゲ ル強度が弱いため倒置法で目視によりその流動性から融 点を判定した。

\subsection{DSC}

試料A97006 $\mathrm{wt} \%$ 七ルロース $/ 55 \mathrm{wt} \% \mathrm{aq} \cdot \mathrm{Ca}(\mathrm{SCN})_{2}$ 溶 波老溶解後ずやかに $25^{\circ} \mathrm{C}$ に急冷し，20日時間保ちゲルを 形成させた.このゲルをSUS製の密閉型容器に約 $25 \mathrm{mg}$ ンプリングし,セイコー電子侏製DSC200で, 室温から $150^{\circ} \mathrm{C}$ まで，年温速度 $5^{\circ} \mathrm{C} / \min$ て測定した。

\section{7 広角 X線測定}

試料A180010 wt\%七ルロース/55wt\%aq.Ca (SCN) 2 溶液を $10 \mathrm{~mm} \phi$ のガラス管に密封し， $110^{\circ} \mathrm{C} て 20$ 分間加熱 したのち、すみやかに $-20^{\circ} \mathrm{C}, 0^{\circ} \mathrm{C}, 20^{\circ} \mathrm{C}, 40^{\circ} \mathrm{C}$ の恒温槽 にいれ，24時間保ちゲルを形成させた。このゲルをX線回 折装置RU-300(侏りガク製)を用いて, MoK $\alpha$ 線を線源と し, 加速電圧 $58 \mathrm{kV}$ ，管電流 $300 \mathrm{~mA}$, 反射法で測定した。 また，同じ条件でガラス管に55wt\%aq.Ca $(\mathrm{SCN})_{2}$ を封入 して測定した。

\section{3. 結果と考察}

\section{1 ゲル化}

Fig.1にセルロース/aq.Ca(SCN) 溶液を $110^{\circ} \mathrm{C}$ から10$60^{\circ} \mathrm{C}$ に急冷させたときのセルロース濃度とゲル化に要し た時間 $\left(\mathrm{t}^{\mathrm{G}}\right)$ の関係を示す。图はそれぞれa) 重合度 $\left.970 ， \mathrm{~b}\right)$ 760 , c) 550 , d) 430 , e) 290 ，f) 180 である。また, Fig.2 には $110^{\circ} \mathrm{C} か ら 10-80^{\circ} \mathrm{C}$ に急冷したサンプルの24時間後の 相状態を示す.Fig.1から明らかなようにゲル化は急冷し 保持した温度 $\left(T_{q}\right)$ が低い，七ルロース濃度が高い，分子 量が高いほど速やかに起こる.Fig.2に示した24時間以内 にゲル化する $\mathrm{T}_{\mathrm{q}}$ とセルロース濃度の領域を見ると, セル ロース濃度が $1 \%$ 以下の低濃度域では分子量の高い試料 の方が高温領域でもゲル化する傾向にあるが、高濃度側 では290以上の重合度 (Fig.2-a-e)では大きな差がない。 重合度1800試料はセルロース䑑度が高濃度側でも他の重 


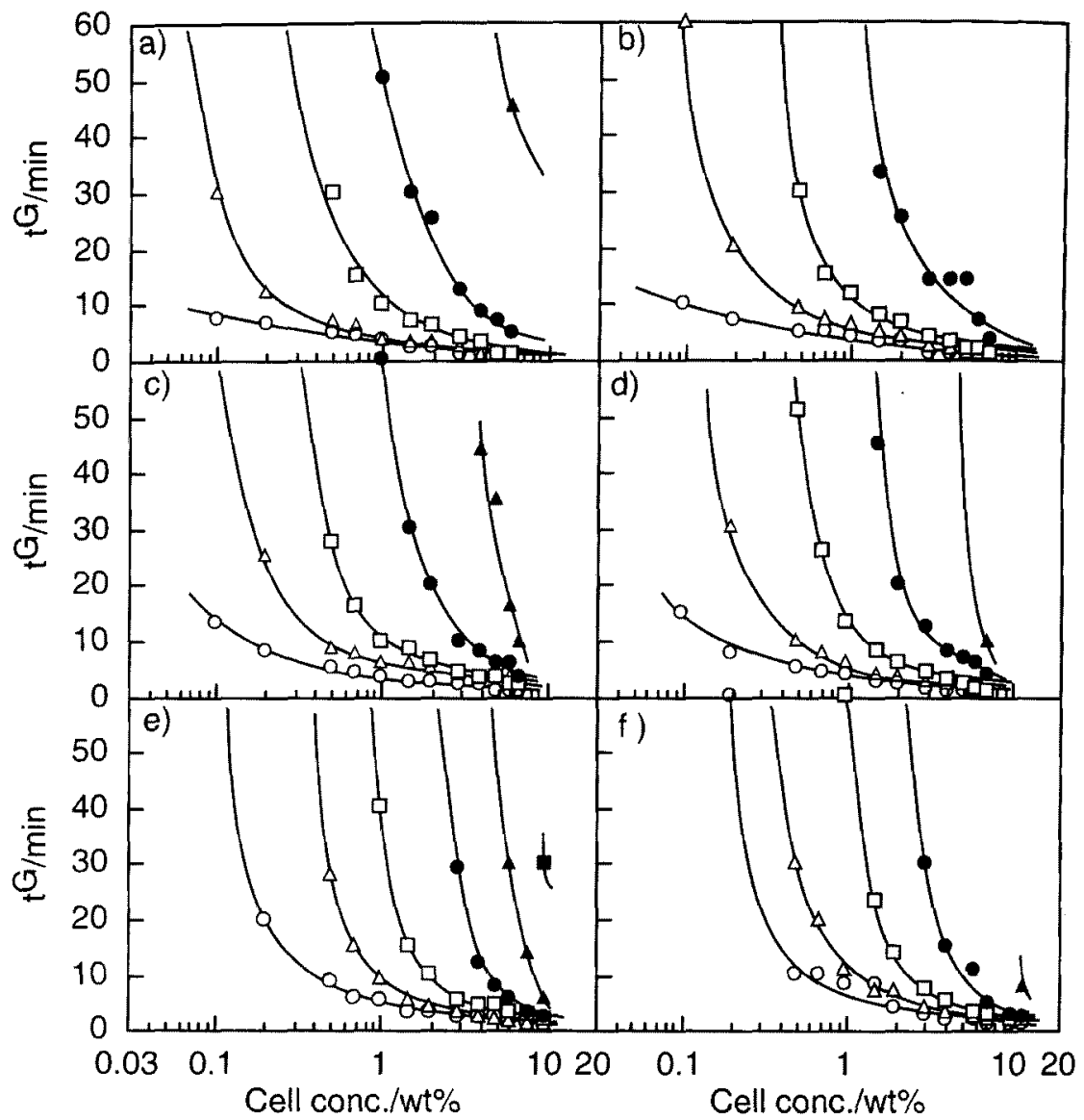

Fig. 1 Relationship between cellulose concentration and gelation time of cellulose $/ 55 \mathrm{wt} \%$ aq.calcium thiocyanate system when the system cooled quickly from $110^{\circ} \mathrm{C}$ to required temperature. Cellulose degree of polymerization ; a) 970 , b) 760 , c) 550 , d) 430 , e) 290 , f) 180 . Gelation temperature : $\mathrm{O}, 10^{\circ} \mathrm{C} ; \Delta, 20^{\circ} \mathrm{C} ; \square, 30^{\circ} \mathrm{C} ; 40^{\circ} \mathrm{C} ; \Delta, 50^{\circ} \mathrm{C} ; 60^{\circ} \mathrm{C}$.

合度の高い試料と比較するとゲル化する温度が低温で, ゲル化領域が狭く，たとえばセルロース濃度が10\%のと ころでは分子量が2900ものと比べても20 C はど低温であ る.また本実験に用いたすへてての試料においてはゲル化 以前に䍝り点が観察され，生成したゲルも白濁していた。 その白濁度はゲル化の温度, 七ルロースの濃度，および 分子量によって異なり，高分子量の試料溶液を低いT ゲル化させたものは光透過性が高く，その弾性も大きい. 一方低分子量のサンプルになるはど，またより高温側で 形成させたゲルはど，より白濁が進み，弾力は減少して

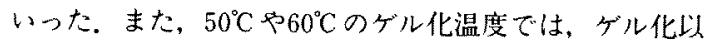
前に溶液中に溇度むらが観察された。Komatsuら[8]はポ リビニルアルコール/水系の降温時のゾルーゲル転移曲 線とスビノーダル曲線执よびバイノ一ダル曲線との関係
を実験的に示しゲル化には液一液相分離を伴う領域( ピノーダル曲線より低温側)と伴わない領域(スピノータ ル曲線よりも高温側)があることまたスピノーダル分解 を起こすがゲル化しない相が存在することを示した。 のことから，スピノーダル分解がゲル化の必要条件およ び十分条件とは限らないが，スピノ一タル曲線より低温 でゲル化する領域では，液一液相分離によって生した瀑 厚相中で結晶化が起こりポリマ一鎖が固定されるとした。 一方, 著者ら[9]は十イロン66/塩化カルシウム/タタノ 一ル系について,最り点より低温でゲル化が起こり, 液一 液相分離によって生じな濃厚相中でゲルの架橋点が形成

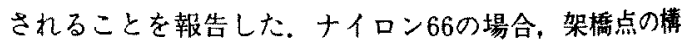
造はその椧却温度域によって異なり，室温付近で形成し たゲルでは濃厚相中でポリマーーポリマー相互作用(徽結 

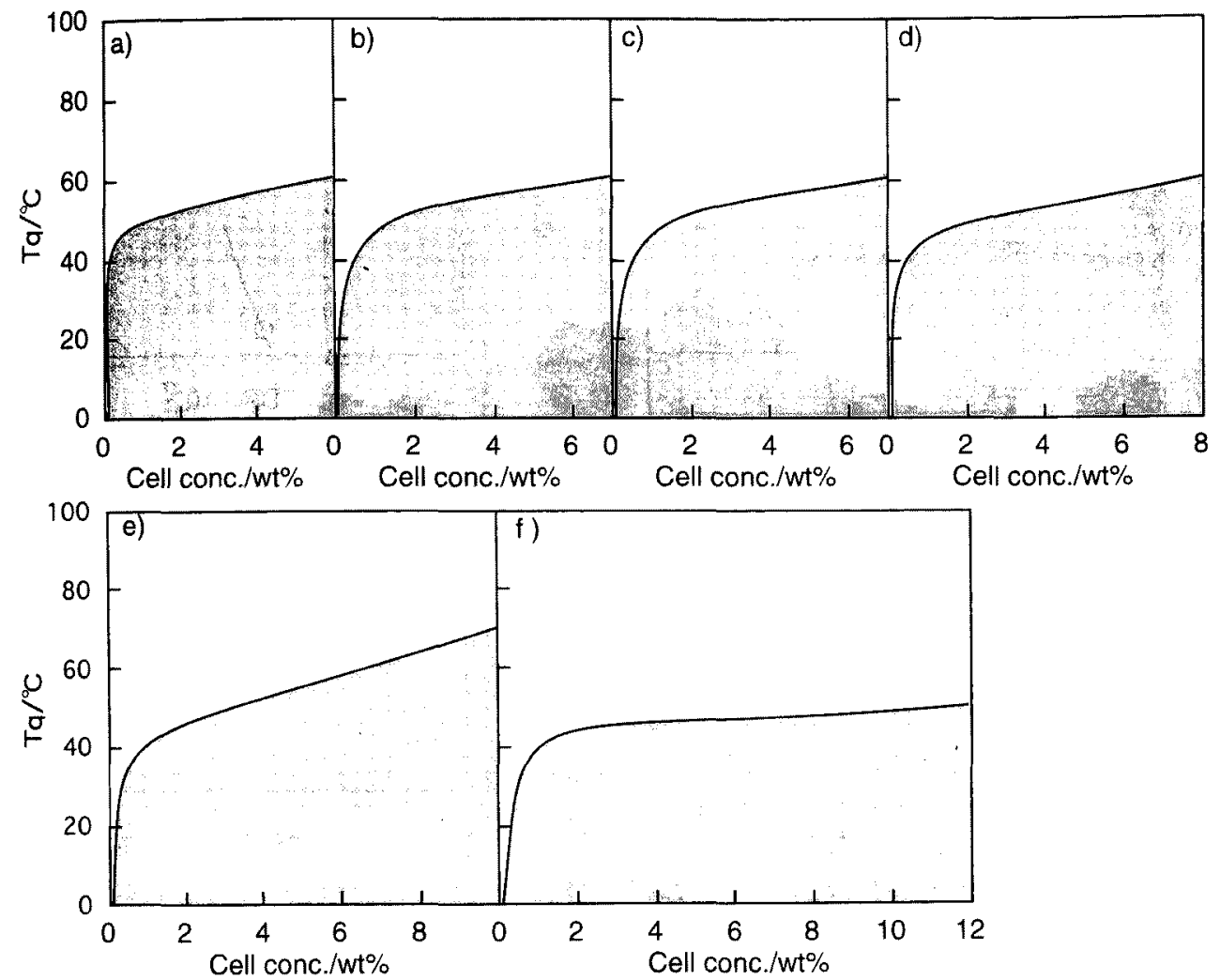

Fig. 2 Gelation phase diagram of cellulose $/ 55 \mathrm{wt} \%$ aq.calcium thiocyanate system after 24 hour when the system cooled quickly from $110^{\circ} \mathrm{C}$ to required temperature. Cellulose degree of polymerization ; a) 970, b) 760 , c) 550 , d) 430 , e) 290 , f) 180 .

晶)とポリマー一溶媒相互作用が関与した 2 種類の架橋点 が存在すること，一方， $0{ }^{\circ} \mathrm{C}$ 以下に急冷却した場合には 湮厚相のポリマー鎖がガラス状態になって絡み合いを持 つたまま運動が湅結され，架橋点となることを示した。 いずれの場合もケル化以前に量り点が観察される場合に は, 液一液相分離による濃厚相中でゲルの架橋点が形成 されている。これらのことから，白濁後ゲル化するセル ロース/aq.Ca (SCN) 2 系でも液一液相分離が起り，濃厚 相中に架橋点が形成されゲル化が誘発された可能性が高 い.

Fig. 3 に $25^{\circ} \mathrm{C}$ で生成したゲルの $10 \%$ 圧縮時の最大応力の 経時変化を示す、a)はセルロース濃度 $0.5 \%$ で重合度の異 なる試料について,b)は重合度が970でセルロース濃度の 巽なる陚料について圧縮時の最大応力を示す。ただし 重合度が180，セルロース濃度が0.5wt\%のサンプルおよ び重合度 970 でセルロース濃度が0.1\%のサンプルはゲル 化した後，ゲルを切り出したが自重で変形し円筒形を保 持できなかった。いずれの条件で生成したゲルも圧縮時
の最大応力が平衡に達するまでに約10時間かかる。また 七ルロース濃度が $0.5 \mathrm{wt} \%$ 以下のサンプルでは時間ととも に離槳が観察され，七ルロース濃度が低く低分子量の茾 ンプルはど離漿の量は萝く，その離漿量は最大で初期の ゲル体積の10\%以内であった. Fig.1に示したようにこれ らのサンプルは30分以内でゲル化したが，巨視的には流 動性を失っても構造の安定化には長時間かかる。この平 衡時の最大応力値と, 重合度およびセルロース浱度の対 数一対数プロットをFig.4のa)，b）にそれぞれ示した。ゲ ルの応力は重合度とともに大きくなるが, 重合度が約 300 以下で重合度の低下とともに急激に圧縮時の応力が小さ くなる．また濃度の增加と共に応力は大きくなる，ポリ スチレンのようにrandom coilと見なせる屈曲性分子鎖の 化学架橋したゲルに対してはゴム弾性理諭が適用でき， 以下の式を用いてゲルのずり弾性率から架橋点間分子量 を求めることができる $[10,11]$.

$$
\mathrm{G}=\rho \mathrm{RT} / \mathrm{Mc}
$$

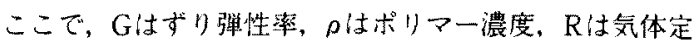




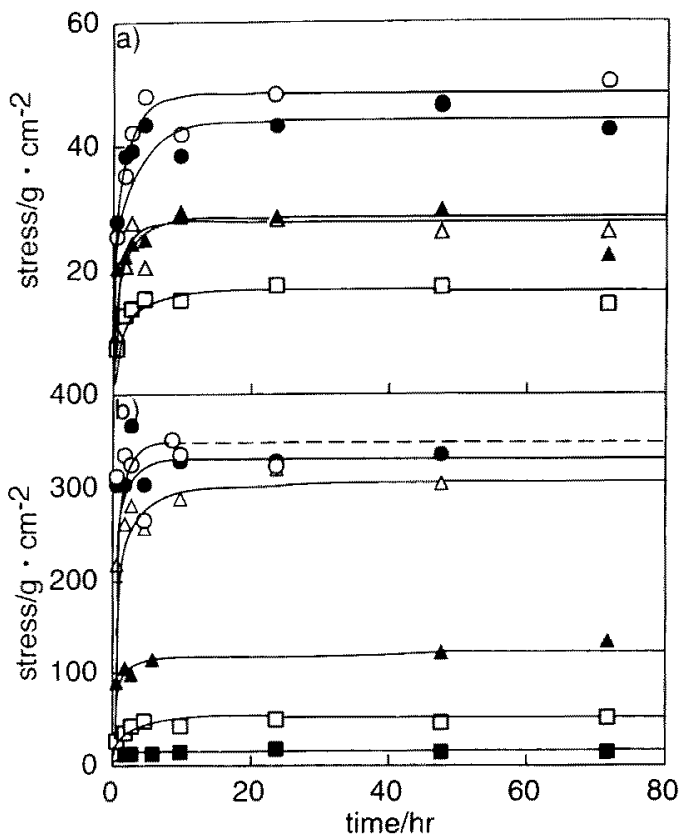

Fig. 3 Relationship between maximum stress at $10 \%$ compression of cellulose $/ 55 \mathrm{wt} \%$ aq.calcium thiocyanate gel generated at $25^{\circ} \mathrm{C}$ and aged time, a) cellulose concentration was $0.5 \mathrm{wt} \%$ with various $\mathrm{DP} . \mathrm{DP} ; \mathrm{O}, 970 ;-760 ; \triangle, 550$; A, $430 ; \square, 290$. b) DP was 970 with various cellulose concentration. Cellulose concen. tration; $O, 4 w t \% ; O, 3 w t \% ; \triangle, 2 w t \%$; $1 \mathrm{wt} \% ; \square, 0.5 \mathrm{wt} \% ; \mathbf{0}, 0.2 \mathrm{wt} \%$.

数，Tは絶刘温度，Mcは架橋点間分子量でる。しかし ながら、Mitchell[12]仕多糖類の多くは分子内水䒺結合と

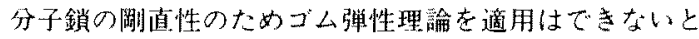
綕諭しだ同系の場合も 4 水和の非解離の $\mathrm{Ca}(\mathrm{SCN})_{2}$ が七 ルロース分子のC5およU゙C6位の酸素原子に溶媒和し，七 ルロース分子のブルコピラノース環平面に溶媒が平行に 㹡がった棈造を取っている[5,6]ため，元来，半属曲性高 分子であるセルロース分子の屈曲性は減少し，溯直性を 増してい当ものと考之られる。合のため(1)式をてのまま 適用して架憍点間分子量を求めることはできないが，ポ リマー泟废の異なるゲルの架橋点部分の構造が同じであ れば、ひずみに对する応力はゲル中の網目棈造を形成し

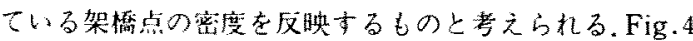
b)に示す上方に濃度に対して応力は比例関係ではないが ゲル中の商分子濃度の增加と其に架橋点数が堌加してい るものと考之られる。一力，Fig.4a）加らDP=300以下で 急激に応力が低下している事寒は，この分子量を境に網
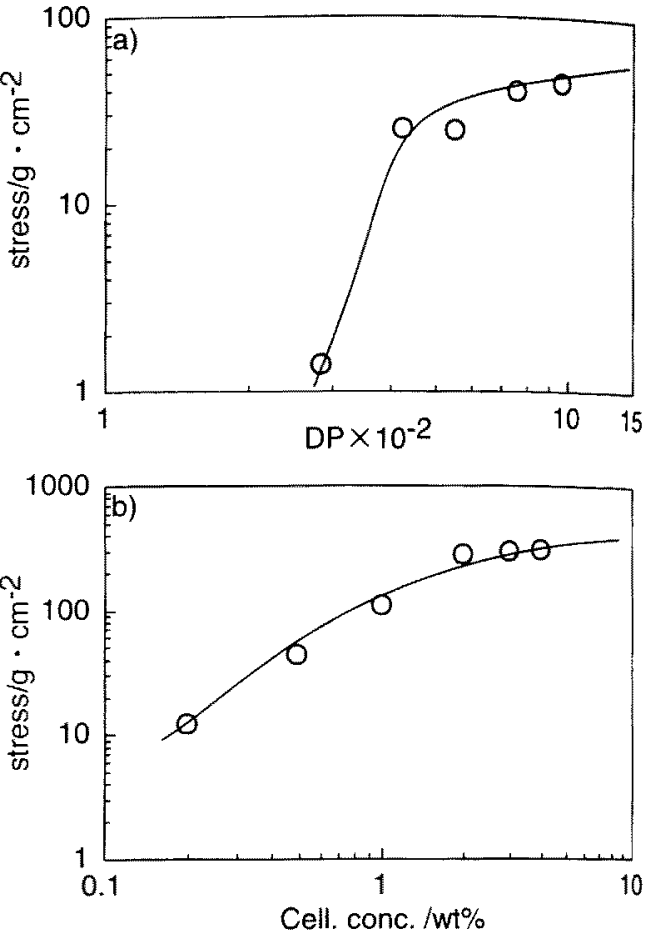

Fig. 4 a) Relationship between maximum stress of $10 \%$ compression after equiblium and degree of polymerization. b) Relationship between maximum stress of $10 \%$ compression after equiblium and cellulose concentration.

目構造に奇与する有效架楿点が減少していること示し ていると思わ札る。無限網目構造を形成するには1 分子 内に最低 2 個以上の架橋点が存在する必要があるか， DP= 300以下では架橋点間分子量の平均値が分子量以上である と考えられる。

\section{2 ゲルの融解}

Fig.5のa)-f)に分子量の異なるセルロース濃度0.1-12 wt \% で，1週間以上それぞれ $-20^{\circ} \mathrm{C}, 0^{\circ} \mathrm{C}, 25^{\circ} \mathrm{C}, 40^{\circ} \mathrm{C}$ 形成させたゲルの融点を示す、3.1節で示したようにケル 化速度や目䘽に上るゲの透明性はゲル化温度により異 なるが、ゲルの融点はゲル化温度にははとんど影翌せず， セルロース濰度が0.5\%以上の領域ではセルロースか55wt\% $\mathrm{aq} . \mathrm{Ca}(\mathrm{SCN})_{2}$ に溶解する温度 (粎 $\left.95^{\circ} \mathrm{C}\right)[4]$ に近い. この融解曲線はFig.2のゲル化の相図のゲル化領域の曲線 の形状と似ているが，その温度は数40 $\mathrm{C}$ 高温側であり。 ヒステリシスを示す。

ゲルの融点からEldrige-Ferryの理諭[13]を用いて、下 記の式によりゲルの架楿点エホルギ一求めることが る。 

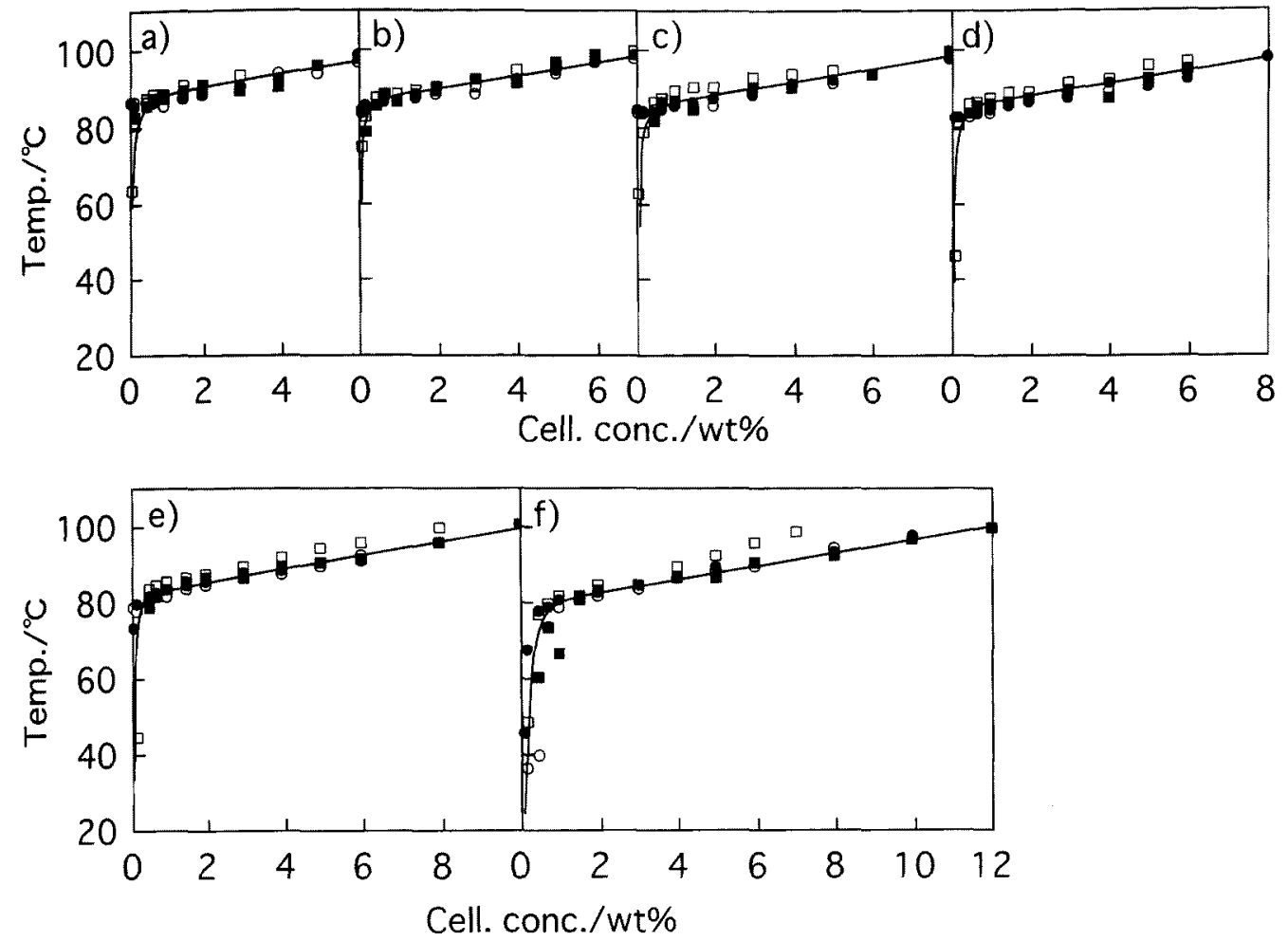

Fig. 5 Relationship between gel melting temperature for cellulose $/ 55 \mathrm{wt} \% \mathrm{aq} . \mathrm{Ca}(\mathrm{SCN})_{2}$ gel aged for lweek and cellulose concentration. Degree of polymerization of cellulose ; a) 970 , b) 760 , c) 550 , d) 430 , e) 290 , f) 180 . Gelation temperature: $\mathrm{O},-20^{\circ} \mathrm{C} ; \mathrm{C}, 0^{\circ} \mathrm{C} ; \square, 25^{\circ} \mathrm{C} ; \square, 40^{\circ} \mathrm{C}$.

$\ln \mathrm{C}=\Delta \mathrm{H}_{\mathrm{c}} / \mathrm{RT}_{\mathrm{m}}+$ (const) ${ }_{1}$

ln $\mathrm{M}_{\mathrm{w}}=\Delta \mathrm{H}_{\mathrm{m}} / 7 \mathrm{RT} \mathrm{m}+$ (const)

ここで, Cはポリマー漂度 $(\mathrm{g} / \mathrm{l}), \mathrm{M}_{\mathrm{w}}$ はポリマーの重量平 均分子量, Rは気体定数, $\mathrm{T}_{\mathrm{m}}$ はゲルの融点 $(\mathrm{K}), \Delta \mathrm{H}_{\mathrm{c}}$ と $\Delta H_{\mathrm{m}}$ は共にゲル中の架橋点 1 モルの生成エネルギーであ る、2分子の会合により架橋点が形成される場合には, $\Delta H_{c}$ と $\Delta H_{m}$ は等しくなる。架橋点が複数の高分子鎖nか ら成る場合は両者の関係は式(4)のようになる[14].

$$
\Delta H_{c}=\Delta H_{m} /(n-1)
$$

Kamideらはセルロース/ $/ 9 \% \mathrm{NaOH}$ 水溶液の濃度の異な る掵却ゲル(熱可逆ゲル)の融点から，架橋点が 2 成分の 会合からなると仮定して (2) 式を用い, その架橋点の生成 エネルギーを $31 \mathrm{~kJ} / \mathrm{mol}$ と見積もった[1]. Hudsonらは(2)(4)式を用いて, セルロース/液体アンモニア/チオシア ン酸アンモニウム溶液をー $12{ }^{\circ} \mathrm{C}$ に冷却して得られる熱可 逆ゲルの架橋点生成エネルギーが150-460kcal/molであり， 架橋点に含まれる高分子鎖数nが約 3 になることを示し た[2].

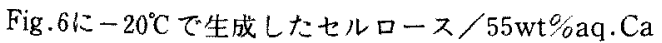

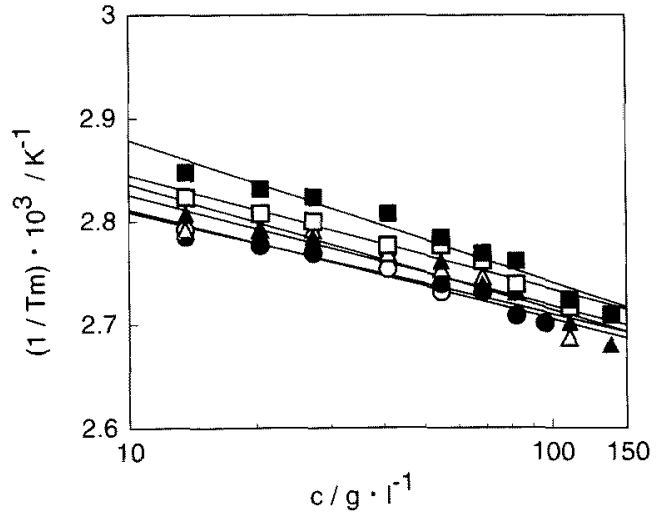

Fig. 6 Plot of $1 / \mathrm{Tm}$ versus $\log \mathrm{C}$, for the Cellulose/ $55 \mathrm{wt} \%$ aq. $\mathrm{Ca}(\mathrm{SCN})_{2}$ gel aged at $-20^{\circ} \mathrm{C}$. Degree of polymerization: $O, 970 ; \bigcirc 760 ; \triangle, 550$; А $430 ; \square, 290 ; \square, 180$.

$(\mathrm{SCN})_{2}$ ゲルの融点の逆数を濃度の対数に対してプロット したものを示す。どの分子量のゲルに対しても融点の逆 
数は濃度 $10 \mathrm{~g} / \mathrm{l}-100 \mathrm{~g} / 10$ 籁囲では襄度の対数に対して直線 で近似できる。この傾きから(2)式を用いて $\Delta H_{c}$ を求奻た。 $0^{\circ} \mathrm{C}, 25^{\circ} \mathrm{C}, 40^{\circ} \mathrm{C}$ で生成したゲルも同様にして、 $\Delta \mathrm{H}_{\mathrm{c}}$ 龙

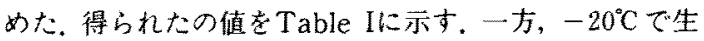
成した $1 \%$ ６\%の濃度のゲルに対してそれぞれ融点の 迸数を分子量の对数に対してプロットしたものをFig.7に 示す。これも直線で近似でき，直線の傾きから(3)式孛用

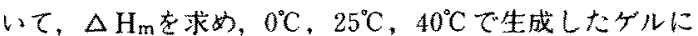
对しても同様の针算を行った。得られた $\Delta H_{\mathrm{m}}$ の值をTable I に示した. Table Iに示した $\Delta H_{\mathrm{c}}$ および $\mathrm{H}_{\mathrm{m}}$ の平均值か

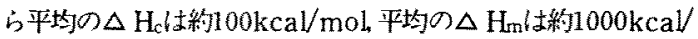
molであったまた(4)式から1架橋点に含まれる高分子 鎖数勾は10本となったこれらの值はセルロース $/ 9 \% \mathrm{NaOH}$ 水溶液の冷却ゲルやセルロース/液体アンモニア／チ才 シアン酸アンモニウム溶液のゲルで得られた架橋点の生 成工ネルギーより大きく，本系のゲルのちがより強固な 架橋点構造を持っているものと考之られる。

Table I $\Delta \mathrm{H}_{\mathrm{c}}, \Delta \mathrm{H}_{\mathrm{m}}$ of cellulose/aq.Ca $(\mathrm{SCN})_{2}$ gel generated in various conditions.

\begin{tabular}{|c|c|c|c|c|c|}
\hline $\begin{array}{l}\text { Gelation } \\
\text { Temp/ } / \mathrm{C}\end{array}$ & $\mathrm{DP}$ & $\begin{array}{c}\Delta \mathrm{H}_{\mathrm{c}} / \\
\mathrm{kcal} \cdot \mathrm{mol}^{-1}\end{array}$ & $\begin{array}{l}\text { Gelation } \\
\text { Temp/c }\end{array}$ & $\begin{array}{l}\text { Conc. } \\
\text { /wt } \%\end{array}$ & $\begin{array}{c}\Delta \mathrm{H}_{\mathrm{m}} / \\
\mathrm{kcal} \cdot \mathrm{mol}^{-1}\end{array}$ \\
\hline \multirow[t]{6}{*}{-20} & 970 & 99 & \multirow[t]{6}{*}{-20} & 1 & 881 \\
\hline & 760 & 106 & & 1.5 & 988 \\
\hline & 550 & 98 & & 2 & 1018 \\
\hline & 430 & 86 & & 3 & 1213 \\
\hline & 290 & 95 & & 4 & 980 \\
\hline & 180 & 76 & & 5 & 1349 \\
\hline \multirow[t]{6}{*}{0} & 970 & 100 & \multirow[t]{6}{*}{0} & 1 & 1044 \\
\hline & 760 & 101 & & 1.5 & 1162 \\
\hline & 550 & 111 & & 2 & 1090 \\
\hline & 430 & 102 & & 3 & 1257 \\
\hline & 290 & 93 & & 4 & 1131 \\
\hline & 180 & 84 & & 5 & 1124 \\
\hline \multirow[t]{6}{*}{25} & 970 & 127 & \multirow[t]{6}{*}{25} & 1 & 1085 \\
\hline & 760 & 108 & & 1.5 & 810 \\
\hline & 550 & - & & 2 & 1221 \\
\hline & 430 & 118 & & 3 & 981 \\
\hline & 290 & 92 & & 4 & 1260 \\
\hline & 180 & 68 & & 5 & 1818 \\
\hline \multirow[t]{6}{*}{40} & 970 & 143 & \multirow[t]{6}{*}{40} & 1 & 1178 \\
\hline & 760 & 101 & & 1.5 & 899 \\
\hline & 550 & 101 & & 2 & 939 \\
\hline & 430 & 110 & & 3 & 1055 \\
\hline & 290 & 95 & & 4 & 1677 \\
\hline & 180 & 77 & & 5 & 757 \\
\hline
\end{tabular}

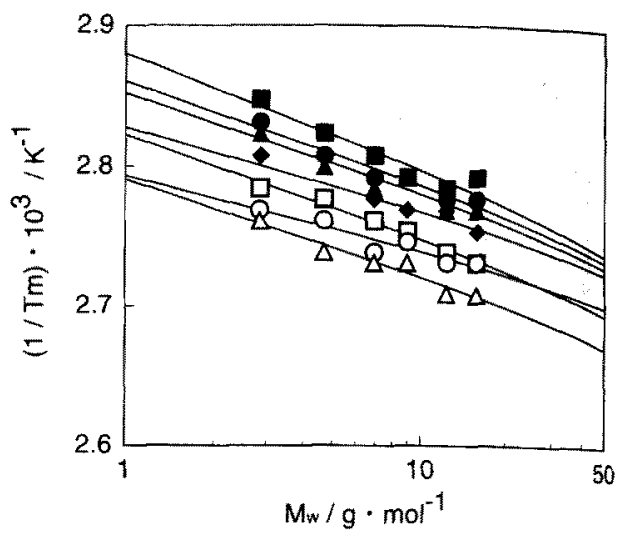

Fig. 7 Plot of $1 /$ Tm versus $\log \mathrm{M}_{\mathrm{w}}$, for the Cellulose/ 55 wt \%aq. Ca $(\mathrm{SCN})_{2}$ gel aged at $-20^{\circ} \mathrm{C}$. Cellulose concentration: $\square, 1 w t \%$; $1.5 \mathrm{wt} \% ; \boldsymbol{\Delta}, 2 \mathrm{wt} \% ; \boldsymbol{\gamma}, 3 \mathrm{wt} \% ; \square, 4 \mathrm{wt} \%$; $0,5 \mathrm{wt} \% ; \triangle, 6 \mathrm{wt} \%$.

Fig.8に試料A97006wt\%溶液を $25^{\circ} \mathrm{C}$ で20時閒保ち生成 させたゲルの䒜温㭙のDSC肃線を示す. $65^{\circ} \mathrm{C}$ から $92^{\circ} \mathrm{CK}$ かけて吸熱ピータがみられたが，非常にブロートで小 なピークである、このピークの終丁温度はFig.5の融解温 度とほほ同しであり，ゲルの融解に起因するしのと考之 られる. 同采のケルの架橋点の基本結合が水素結合加 なると仮定して，吸熱量からゲル架橋点の密度を概算し た。昅熱量はゲル全体の単位重量急たり $0.5 \mathrm{~J} / \mathrm{g} ゙$ り， セルロース重量当たりに換算すると $8.3 \mathrm{~J} / \mathrm{g}$ ，クルコース 単位当たり $0.3 \mathrm{kcal} / \mathrm{mol}$ である.グルコ一ス靽位当たり分 子間の水素結合はC2-OHとC6-OHの 2 力所で可能, 水素 結合は 2 分子会合,まな水素結合のエホルギーが約5 kcal $\mathrm{mol}^{-1}[15]$ でることを考虑すると、クルコース単位当た

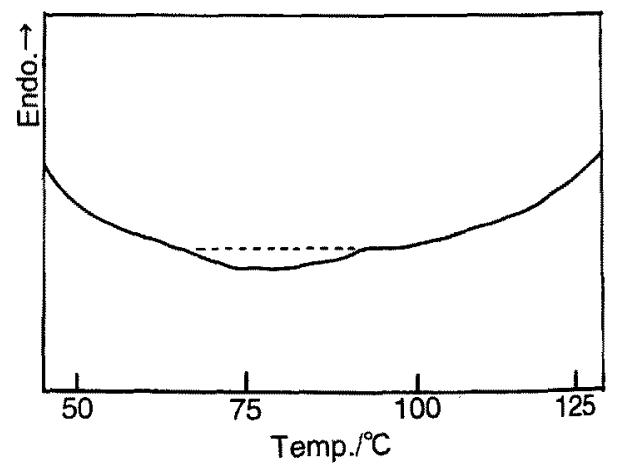

Fig. 8 DSC curve of cellulose $/ 55 w t \% a q . \mathrm{Ca}(\mathrm{SCN})_{2}$ gel with 6 wt $\%$ cellulose concentration and $\mathrm{DP}=970$ aged at $0^{\circ} \mathrm{C}$ for $20 \mathrm{~h}$. 
$\eta て ゙ は$ 約 $5 \mathrm{kcal} / \mathrm{mol}^{-1}$ の水素結合が可能となり, $\mathrm{DP}=970$, 七ルロース溄度 $6 \%$ のゲルではグルコースは17個に 1 個 の㓶合で架橋点に含まれていることになる．先の同系の ゲルの架橋点が約10本の高分子銷からなりその生成工ネ ルギーが約1000kcal/molであることを考虑すると，1架 橋点当たりに1本の分子鎖の連統した20個のクルコース か架橋点に含まれていることになるので，平均化した構 造では20個のクルコースが架橋点に含まれ，続く約320個 のグルコースは架橋点には含まれず，また20個のクルコ 一スか架橋点に含まれるといった構造が提案できる。こ の結果は, Fig4.a)でポリマーの濃度が0.5wt\%と異なる 実験ではあるが重合度が300以下で圧樎時の応力が急に減 少し,平均の架橋点間重合度が 300 と考之られることと一 致する。

\section{3 ゲルの榑造}

Fig. 9 に $-20^{\circ} \mathrm{C}, 0^{\circ} \mathrm{C}, 20^{\circ} \mathrm{C}, 40^{\circ} \mathrm{C}$ でそれぞれ24時間生 成させたゲルと溶媒のX線回折图を示寸、ゲルの生成温度 に注関倸なく、わずかに $\theta=5.1^{\circ}$ 付近にピークが観察され るが、ブードなピークでありはとんどアモルファス状 態であるこのピーク位置はCuKa線に換算すると $2 \theta=11.1^{\circ}$ に相当する.この值はちょうどセルロースII型結晶の (110) 012.8 とセルロース/aq.Ca (SCN) ${ }_{2}$ 付加化合物で観察され $た 10.5^{\circ}[4]$ の中閒に相当する.七ルロース/aq. $\mathrm{Ca}(\mathrm{SCN})_{2}$ 付加化合物ではセルロースの水素結合はほほ切断きれて, 昇温によるミクロブラウン運動の增加によって溶解して いくなめの結晶の融解熱はDSCでは検出できなかったこ と[4]を考虑すると、このゲルの架橋点はセルロースII型 由来の結晶構造の面間隔がわずかに広がったような棈造 である可能性が高く,3.2節でゲルの基本結合をセルロー スの水素結合と仮定したことを支持する。しかし，その 规則性も密度も非常に低く，ほほアモルファスであると

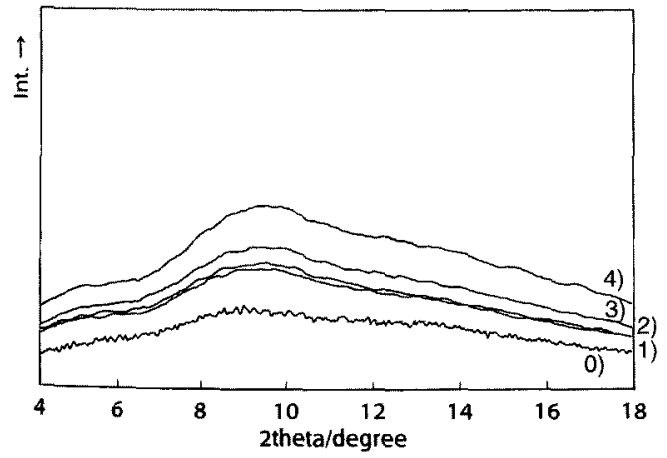

Fig. $9 \mathrm{X}$-ray spectorograph of cellulose $/ 55 \mathrm{wt} \%$ aq.Ca $(\mathrm{SCN})_{2}$ gel aged at various temperature for 24h. Gelation temperature ; 1) $\left.-20^{\circ} \mathrm{C}, 2\right) 0^{\circ} \mathrm{C}, 3$ ) $25^{\circ} \mathrm{C}$, 4) $\left.40^{\circ} \mathrm{C} .0\right) 55 \mathrm{wt} \%$ aq. Ca $(\mathrm{SCN})_{2}$.
言える。

\section{4. 結 論}

本研究で得られた結果は次の通りである。

(1) 七ルロース $/ 55 \mathrm{wt} \%$ aq.Ca (SCN) 溶液柔のゾルー ゲル転移の相図を明らかにした。ゲル化速度はセルロー スの分子量・濃度が高いはど、またゲル化温度が低いほ ど速いが，24時間後のゲル化領域は分子量には大きく影 響されない。

(2)セルロース $/ 55 \mathrm{wt} \% \mathrm{aq} \cdot \mathrm{Ca}(\mathrm{SCN})_{2}$ 溶波系ゲルはゲ ル化後もその弾性率は大きくなりほほ10時間で平衡に達 する。

(3) セルロース $/ 55 \mathrm{wt} \%$ aq.Ca $(\mathrm{SCN})_{2}$ ゲルは溶液の液ー 液相分離に上る漕厚相の生成に起因する可能性が高い。

(4)ゲルはアモルファスであり、ゲルの融点から求めた ゲル架橋点の生成エネルギーは約 $1000 \mathrm{kcal} / \mathrm{mol}$ である。

\section{文献}

1. K. Kamide, M. Saito, and K. Yasuda, ACS SYMPOSIUM SERIES, 489, 184 (1992).

2. S. M. Hudson, and J. A. Cuculo, J. Polym. Sci. Polym. Chem. Ed., 20, 499 (1982).

3. H. E. Williams, J. Soc. Chem. Ind., 40, 221 T (1921).

4. M. Hattori, Y. Shimaya, and M. Saito, Polym. J., 30, 37 (1998).

5. M. Hattori, T. Koga, Y. Shimaya, and M. Saito, Polym. J., 30, 43(1998).

6. M. Hattori, Y. Shimaya, and M. Saito, Polym. J., 30, 49 (1998).

7. W. Brown and R. Wirkström, Eur. Polym. J., 1, 1 (1965).

8. M. Komatsu, T. Inoue, and K. Miyake, J. Polym. Sci., Polym. Phy. Ed., 24, 3030 (1986).

9. M. Hattori, and M. Saito, Polym. J., 28, 139 (1996).

10. E. Klein, and E. Jenkel, Z. Naturforsch., 7a, 800 (1952).

11. L. R. G. Treloar, "The Physics of Rubber Elasticity", $3^{\text {rd }}$ Ed., Clarendon Press, Oxford, 1975, p65.

12. J. R. Mitchell, J. Texture Studies, 11, 315(1980).

13. J. E. Eldridge and J. D. Ferry, J. Phys. Chem., 58, 992 (1954).

14. M. A. Harrison, P. H. Morgan and G. S. Parks, Eur. Polym. J., 8, 1361 (1972).

15. H. Sobue, "Cellulose Handbook", H.Sobue and N. Migita, Ed., Asakura, Tokyo, 1958, Chapter I, p14. 